\title{
RECENSÕES
}

Tobcr, Karl - Urteile und Vorurteile über Literatur. Stuttgart Berlin Köln Mainz, W. Kohlhammer Vel lag, 1970.

Sob o titulo Conceitos e Preconceitos sôbre a Literatura, o A., catedrático e diretor do Instituto de Germanística da University of the Witwatersrand (Johannesburg), apresenta um estudo crítico dos métodos desenvolvidos pela crítica literária no período compreendido entre o século XVIII e os nossos dias.

No primeiro capítulo, Tober apresenta um panorama das três grandes fases da crítica literária moderna, nascidas do passo inicial dado no século XVIII, quando, sob a influência de Herdcr, foram realizadas as primei:as sinteses críticas e históríco-litenárias. Trata-se a) do historicismo positivista_filológ co, b) da interpretação filosófica e c) da interpretação ahistórica, imanente. Cada uma dessas correntes é comentada exaustivamente, mediante elucidação minuciosa de suas caracter ísticas e indicação de seus principais representantes. Nesta parte, depara-se o leitor com uma rica fonte de informaçōes acêrca do que já foi realizado no âmbito da crítica literária, pois, além de expor os objetivos de cada método, o A. destaca com imparcialidade tanto suas limitaçōes quanto seus resultados positivos. Assim, reconhece que a fase positivista-filológica nos legou valiosas contribuições para o desenvolvimento da história da literatura, mas, em cont apartida, pouco realizou no âmbito da interpretação literária. Na etapa seguinte, voltada para a interpretação filosófica, a crítica literária tornou-se, segundo Tober, "uma ciência do Homem, que compreende a vida por intermédio do ato da experiência, sustentado pela (...) 'totalidade da vida espiritual'" (1); mas tal abordagem, por sua vez, "resultou necessàriamente em uma valorização extremada do conteúdo, enquanto as formas de expressão da obra de arte eram consideradas cada vez menos" (2) Na fase ahistórica, finalmente, Tober sublinha que o crítico se propunha a "inte: pretar a obra literária como produção do artista, a partir do texto" (3) e que a obra literária era considerada "um fenômeno a ser compresndido a partir de suas qualidades intrínsecas" (4).

(1) pg. 14 .

(2) pg. 14 .

(3) pg. 14 .

(4) pg. 15 . 
Simultâneamente, o A. ressalta a "relação entre literatura e história (...) na qualidade de problema central das considerações crítico-literárias" (5), e se propõe discutir as possibi'idad s da divisão da literatura em períodos claramente definidos, recorrendo ao excmplo concreto do têrmo "romantismo" Neste contexto, Tober oferece um apanhado histórico dos caminhos seguidos pela pesquisa crítico-literá ia, no sentido de deslindar a qu'stão da determinação de períodos literários. Desenvolve, portanto, uma minuciosa enumeração e respectiva descrição das teorias e dos métodos elaborados por expoentes da crítica literá: ia, tais como Paul Kluckhohn, Ricarda Huch, Hermann August Korff, Oskar Walzel, Fritz Strich, Marianne Thalmann, Emil Staiger e outros. De acôrdo com sua tendência, Tober salienta tanto as contribuições positivas quanto as falhas de cada um dos métodos descritos, e ao mesmo tempo procu'a mostrar "quão restritos são os resultados de um método puramente histórico ou filosófico ou imanente" (6). Encontra-se aqui a atitude polêmica do A., a constituir o ponto de partida, a razão de ser da obra enfocada neste momento. O A. propõe a seguinte tese: torna-se impossível "esperar que uma das três correntes ofereça tôdas as respostas às questões da ciência c ítico-literária; não raro essas correntes são confrontadas umas com as outras, como se fôssem alternativas irreconciliáveis (...)" (7). O objetivo de Tober consiste em defender a integração, a interpcnetração dialética dos três métodos, pois, conforme explica no prefácio, "após a extinção do anti-historicismo talvez haja agora a primeira genuina possibilidade de desenvolver um método que admita o específico, sem negar a totalidade" (8). A fim de corroborar sua tese, Tober confronta, no segundo capitulo, a obra de dois autores de reconhecido mérito, argumentando: "Procuramos descrever as possibilidades de reconhecimento, mas também as formas cristalizadas de pensamento e os limites do reconhecimonto da teoria literá ia e da crítica autônoma, através de um confronto entre as obras de René Wellek e Northrop Frye" (9). A partir dêste confronto, deduz o A. que sòmente $o$ intercâmbio das abordagens histórico-positivista, filosófica e imanente possibilitará a plena realização do sentido e das tarefas da ciência crítico-literária, ou seja: a correta interpretação e avaliação de uma obra literária.

\section{MARION FLEISCHER}

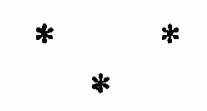
(5) pg. 11 .
(6) pg. 28 .
(7) pg. 42 .
(8) pg. 10 .
(9) pg. 64 . 